\title{
Farklı Akustik Ortamların Çalgı Performansına Etkisinin İncelenmesi ${ }^{1}$
}

\section{Investigation of The Effects of Different Acoustic Environments on Instrument Performance}

\author{
Alper DEMIRAY ${ }^{D}$, M.E.B. Bolu Güzel Sanatlar Lisesi, demiray_alper@hotmail.com
}

Yavuz DURAK ${ }^{\text {ID }}$, Dr. Öğr. Üyesi, Bolu Abant İzzet Baysal Üniversitesi, ydurak27@gmail.com

\begin{abstract}
Demiray, A. ve Durak, Y. (2021). Farklı Akustik Ortamların Çalgı Performansına Etkisinin İncelenmesi. Batı Anadolu Eğitim Bilimleri Dergisi, 2021(2), 650-672.
\end{abstract}

Öz. Ülkemizde müzik eğitimi veren kurumlarda, çalgı eğitimleri ile ilgili gerek teknik, gerekse de müzikal sorunlara dair son yıllarda önemli çalışmalar yapılmaktadır. Bu sorunlar değerlendirildiğinde çalgı odalarındaki akustik problemlerden kaynaklı dikkat dağınıklığı, odaklanma problemleri ve çalgı performansına olumsuz etkilerinin derinlemesine araştırılması kanısına varılmıştır. Bu araştırmanın amacı; eğitim fakültesi güzel sanatlar anabilim dalı müzik bölümlerindeki çalgı odalarının akustik durumları, bunun öğrencilerin çalgı performansları sırasında dikkat ve meditasyon değerlerini ne düzeyde etkilediğini tespit etmek ve olası problemlere çözüm bulmaktır. Bu kapsamda, katılımcıların bireysel çalgı odalarındaki performansları ele alınarak, çeşitli çalgıların akustik farklılıklara (yalıtılmış ve yalıtılmamış odalar) göre dikkat ve meditasyon değerleri yorumlanmıştır. Bireysel çalışma odalarındaki akustik durumlara göre farklı çalgıların dikkat ve meditasyon süreçlerinin nasıl etkilendiğine dikkat çekmek, mevcut olan ve yeni yapılacak olan müzik kurumlarındaki çalışma odalarının akustik donanımları hakkında fikir vermek bakımından araştırmanın önemli olduğu düşünülmektedir. Araştırmada yarı deneysel araştırma modelinden kontrol grupsuz son test desen ve nitel araştırma yöntemlerinden uygulama öncesi ve sonrası için yapılandırılmış görüşme formları kullanılmıştır. Araştırmada katılımcılar üzerinde akustik açıdan oda değişkeninin etkilerine bakılmıştır. Çalgıları birbirinden farklı sekiz katılımcı, farklı akustik ortamlarda çalgı performansı sergilemiştir. Performans sırasında kafa bölgelerine Neurosky Mindwave Mobile 2 EEG cihazı takılmış ve katılımcıların anlık dikkat ve meditasyon değerleri üç farklı oturumda ölçülmüştür. Uygulama sonrasında her katılımcının ayrı odalarda alınan verilerinin ortalamaları alınmış ve birbirleriyle karşılaştırılmıştır. Elde edilen bulgular doğrultusunda, bütün katılımcıların dikkat verileri akustik açıdan yalıtılmış ve düzenlenmiş odada daha yüksek, meditasyon verilerinde ise bireysel farklılıklar gözlenmiştir. Akustik açıdan yalıtılmış odada çalgı performansı sergileyen kişilerin dikkatlerinin daha iyi olduğu sonucuna ulaşılmıştır.

Anahtar Kelimeler: Akustik, Çalgı eğitimi, Neurosky Mindwave Mobile 2.

\begin{abstract}
The purpose of this research; The aim of this study is to determine the acoustic conditions of the instrument rooms in the music departments of the education faculty, fine arts department, to determine how much this affects the attention and meditation values of the students during the instrument performances, and to find solutions to possible problems. In this context, attention and meditation values of various instruments were interpreted according to acoustic differences (insulated and uninsulated rooms) by considering the performances of the participants in individual instrument rooms. In the research, structured interview forms were used for the post-test design without control group from the quasi-experimental research model and for
\end{abstract}

\footnotetext{
${ }^{1}$ Tezden üretilmiş yayın
} 
the pre- and post-application qualitative research methods. In the study, the effects of the room variable on the participants were examined in terms of acoustics. Eight participants with different instruments performed in different acoustic environments. During the performance, the attention and meditation values of the participants were measured with the Neurosky Mindwave Mobile 2 EEG device. Afterwards, the averages of the data of each participant in separate rooms were taken and compared with each other. In line with the findings, the attention data of all participants were higher in the acoustically isolated room, and individual differences were observed in the meditation data. It has been concluded that the attention of people who perform musical instruments in an acoustically isolated room is better.

Keywords: Acoustics, Instrument education, Neurosky Mindwave Mobile 2. 


\section{Extended Abstract}

Introduction. It is known that hand-eye coordination, auditory, physical and motor skills functions, which are among the mental functions in the process of performing instrument performances, are formed in an integrity. Noise control of individual study rooms must be made in order to conduct instrument training in a healthy way. Demirkale (2007) stated that environmental noises do not directly affect the mental health of people, but they accelerate and increase existing mental illnesses. The hypothesis of this study was created with the idea of how external factors (noise) affect the people performing in individual instrument study rooms when the musical functioning of the brain is considered. When the studies on the acoustic conditions of individual study rooms in music institutions in our country were examined, it was stated that the problems in the instrument study rooms (physical inadequacy, etc.) affected individuals and their instrument performances. In this context, using today's technologies, "the effect of different acoustic environments on instrument performance" was investigated, attention and meditation values were examined with Neuro Experimenter Version 6.2 software while the Neurosky Mindwave Mobile 2 EEG device was connected to the people performing in these rooms, improving the educational environment in the rooms in terms of acoustics. This research was carried out with the aim of.

Method. In this study, one of the experimental research methods, a post-test design without a control group was used. In this context, the effect of the participants selected from the Bolu Abant izzet Baysal University Faculty of Education Department of Music Education Program on the instrument performance of the participants in two categories (acoustically isolated and not isolated) on the individual instrument room variable was examined. A total of eight students, one for each instrument, from the instruments (baglama, guitar, individual vocal training, piano, violin, viola, cello, flute) studied in the music department participated in the experimental phase of the study. Each student performed a piece of work in a non-acoustically insulated room in 3 sessions with Neurosky's Mindwave Mobile 2 device attached. On a separate day, they exhibited the same work in 3 sessions in an acoustically insulated room. The measurements were made in three sessions, taking into account the participants' adaptation processes to two different environments, the process of getting used to the device used, and the process of getting used to the performance sounds they obtained from the environment, and the data were evaluated according to the average of the three sessions. In addition, semi-structured interview questions were prepared and reported with the participants.

Results. According to the performance exhibited by all participants in different acoustic environment, attention values were higher, showing positive difference from 6 units to 24 units in the acoustically insulated room. Based on this result, it can be said that students' attention, focus and concentration will be at a better level for instrument training and performance in acoustically isolated and arranged room. Individual differences emerged in the values of meditation according to the performances of all participants. Baglama, guitar, side flute, viola participants high; Individual vocal training, violin, cello participants' low and neutral direction data difference of piano participants are observed. However, when the negative data were examined, it was found that the difference was at most 2 units, and accordingly, the participants with low meditation data were not actually very different from each other in two different acoustic rooms. When the underlying reasons are examined, it is thought that as the attention span to the piece increases, the concentration on the note and playing techniques leads to a departure from interpretation and the inability of individuals to realize the emotional expression created by the piece.

Discussion and Conclusion. When the data were examined, the differences between the two rooms varied according to the instruments. According to these data, individual differences are observed in the meditation data of the participants in the instrument performances exhibited in two rooms in 
terms of acoustics. Accordingly, the acoustic difference of the room varied in the meditation values of the participants according to the working principles of different instruments and resonance habits. Alexander (2016) stated that a safe learning environment should be created in which students will not be afraid of making mistakes and where they can take musical risks, and stated that learning environments should offer creative experiences (cited in Çenberci, 2019, p. 107). The findings obtained in this sense can be interpreted as the result that individuals' working habits cause different feelings according to the environment they are in, so that working habits should be provided with environment arrangements that can work with healthy, efficient and clean sensations. In order for instrument training to be more efficient, all kinds of music institutions should go to acoustic insulation and arrangements in individual study rooms. Acoustically insulated and arranged rooms should be created by experts as a standard room model. Thus, learners can get rid of different auditory perceptions over time and their performance efficiency can be increased. More lessons in the field of acoustics should be added to the formal education course contents in order to make sense of and eliminate the acoustic problems that students experience in the rooms. 


\section{Giriş}

Müzik dinlerken duyduğumuz seslerin düzenli bir ses örüntüsüne sahip olması, sıradan seslerden ayıran en önemli özelliğidir. Müzik, "seslerin biçimsel güzelliğini ve duygusal ifadesini birleştirme sanatıdır veya dinleyicilerde estetik bir tepki uyandırmayı amaçlayan uyumlu bir ses sıralaması üretebilecek şekilde ses perdelerini tasarlayabilme sanatıdır" (Parker, 2015, s.2). Seslerin biçimsel işleyişinin düzensiz bir şeklide oluşması ve ani değişimleri, insanların işitme-algılama durumlarını olumsuz yönde etkileyebilir. Bu durumdaki ses örüntüsüne gürültü denmektedir. Gürültünün insanlar üzerinde birçok olumsuz etkisi olduğu bilenmektedir. Bunlardan bazıları; işitme bozukluğu gibi fiziksel deformasyon, konuşmaların engellenmesiyle oluşan iletişim sıkıntıları; uyku, ruh sağlığı, iş performansı vb. üzerindeki olumsuz etkileridir.

Genel, özengen ve mesleki müzik eğitimi veren kurumlarda çalgı eğitimi bireysel çalgı çalışma odalarında veya kurum olanaklarına göre farklı dersliklerde sürdürülmektedir. Bu eğitimin verimli bir şekilde sürdürülmesi için eğitim ortamının düzenlenmesi önem arz etmektedir. Bir müzik kurumunun fiziksel koşulları ve problemleri ele alındığında ısı, ışık, temizlik vb. unsurlarından daha önce gelmesi ve önem verilmesi gereken koşullar ses yalıtımı ve akustik düzenlemedir. Aydın'a (1998) göre, "akustik tasarım ve ses yalıtımının kötü olması, okullarda gürültü kirliliği artıran faktörlerin başında gelmektedir" (akt. Bulunuz, Bulunuz ve Tuncal, 2017, s.640). Bireysel çalışma odalarında çalgılarını çalışan öğrencilerin, dış ve iç ortam gürültülere maruz kalarak süreç içerisinde performanslarının etkilendiği görülmektedir.

Çalgı eğitimi uzun ve meşakkatli bir süreci kapsamaktadır. Bu süreçte öğrencinin ihtiyaçlarının belirlenmesinde, öğrenme ortamlarının düzenlenmesinde ve bireysel özellikler gözetilerek öğretim programının hazırlanmasında hayati bir role sahip olan müzik öğretmeninin, eğitim sürecinde çalgısını etkin kullanması çok önemlidir. Bu yüzden çalgı eğitiminin iyi koşullarda sağlanması gerekmektedir. Müzik öğretmenleri, öğrenim gördüğü kurumlarda çalgı eğitimini ve çalışmalarını bireysel çalgı çalışma odalarında sürdürmektedir. Çalgı eğitiminin çocukluktan başlayıp yaşam boyu devam ettiği düşünüldüğünde, bireysel çalışma odalarının akustik durumu göz önünde bulundurulması gereken durumlar arasında yer almaktadır. Bireysel çalışma odalarının akustik açıdan yalıtımlı olması öğrencilerin dikkat sürelerinin artmasına olanak sağlayacağı gibi önemli davranışlar kazanması ve etkili çalışma alışanlığı edinmelerine de yardımcı olur. Şendurur (2001), bireysel çalışma sürecinde çalışma mekânlarının, öğrencinin çalışmalarını olumlu yönde etkileyecek bir durumda hazırlanıp, planlanması gerektiğini ifade etmiştir. Yanı sıra bir çalışma odasının; akustik, ışık, ısı, nem, temizlik yönünden çalışmaya uygun olması gerektiğini, çalışma için gerekli nota sehpası, sandalye ve buna benzer ders araçlarının bulunması gerektiğini belirtmiştir (s. 165).

Çalgı eğitiminin sağlıklı bir şeklide yürütülmesi için bireysel çalışma odalarının gürültü kontrolü mutlaka yapılmalıdır. Demirkale (2007), çevresel gürültülerin, insanın ruh sağlığını direkt olarak etkilemediğini, ancak mevcut ruh hastalıklarını hızlandırdığını ve arttırdığını dile getirmiştir. Bireysel çalışma odalarındaki akustik problemler, öğrencilerin çalgı çalışmalarına, ders kalitesine, performanslarına doğrudan ve dolaylı olarak etki yapabilmektedir. Eserin akıcılığını, müzikalitesini, çalışma süresini doğrudan etkilerken; zihinsel yorgunluk, çalışma isteksizliği, dikkat dağınıklığı vb. etmenleri de dolaylı yönden etkilemektedir.

Çalgı performanslarının gerçekleştirilme sürecinde zihinsel işlevler arasında yer alan el-göz koordinasyonu, işitsel, bedensel ve motor becerileri fonksiyonlarının bir bütünlük içerisinde birbirine bağlı olarak oluştuğu bilinmektedir. Bu durumu Şendurur ve Barış (2002, s.166), "eğitimin bütün dallarında olduğu gibi müzik eğitiminde de amaç bireyi duyuşsal, bilişsel ve devinişsel açıdan 
geliştirmek ve onun davranışlarında bu yönde istendik değişiklikler oluşturmaktır" olarak belirtmişlerdir.

Müziğin bilişsel ve duygusal yönü son yıllarda çokça merak edilen bir konu olmuştur. Müzik ve beyin ilişkisi sadece tıp alanında değil, müzik alanında da çalışanların disiplinlerarası konusu olmuştur. Uçan (1997), "bilişsel davranışlar daha çok zihne ve onun biyolojik temeli olan beyin ve sinir sistemine, duyuşsal davranışlar daha çok hisse ve onun biyolojik temelini oluşturan belirli iç salgı bezleri sistemine dayanmaktadır" (s.94). Ayrıca, Levitin (2015), insanın davranışları ve düşünsel boyutları beynin belli yerlerinde işlendiğini, müzikal düşünme becerileri neredeyse bütün kısımları ve sinirsel alt sistemi kapsadığını belirtmiştir (s.102).

Ayata ve Aşkın (2009), "müzik yapmak, iletişim, işbirliği, grup koordinasyonu ve sosyal bütünlük gibi evrimsel fonksiyonları içerir. Aynı zamanda beynin, algılama, hareket, duygu, öğrenme ve hafıza gibi hemen hemen bütün zihinsel fonksiyonlarını faaliyete geçiren çok yönlü bir iştir" (s.15). Beynin müzikal işleyiş biçimi ele alındığında, bu mükemmel sistemi etkileyen dış faktörlerin (gürültü), bireysel çalgı çalışma odalarında performans sergileyen kişileri nasıl etkilediği düşüncesi ile bu araştırma gerçekleştirilmiştir. Bu araştırmanın problem cümlesi; "Farklı akustik ortamların çalgı performansına etki durumu nedir?" olarak belirlenmiştir. Ülkemizdeki müzik kurumlarında yer alan bireysel çalışma odalarının akustik durumları ile ilgili araştırmalar incelendiğinde (Özmenteş, 2004; Aşmet Köse, 2004; Jelen, 2013; Akgün, 2011; Bulunuz vd., 2017; Mutlu, 2018; Özmumcu, 2019; Kurtyener, 2019; Daloğlu, 2019), çalgı çalışma odalarındaki problemlerin (fiziksel açıdan yetersizlik vb.) kişileri ve çalgı performanslarını etkilediğinden bahsedilmiştir. Durak ve Baytemur (2019), öncelikle müzik eğitimi veren tüm kurumların akustik değerlendirmeleri incelenerek fiziksel şartlarının sağlanması gerektiğini ve sağlıklı bir müziksel ortamın ancak yalıtılmış ve akustik açıdan düzenlenmiş mekanlarda gerçekleşebileceğini dile getirmişlerdir. Bu bağlamda, günümüz teknolojilerinden yararlanarak "farklı akustik ortamların çalgı performansına etkisi" araştırılmış, bu odalarda performans sergileyen kişilerde Neurosky Mindwave Mobile 2 EEG cihazı bağlı iken Neuro Experimenter Version 6.2 yazılımı ile dikkat ve meditasyon değerleri incelenmiş, odalardaki eğitim ortamının akustik açıdan daha iyi hale getirilmesine yönelik öneriler getirmek amacıyla bu araştırma gerçekleştirilmiştir.

\section{Amaç ve Önem}

Bu araştırmanın amacı; müzik bölümlerindeki bireysel çalgı çalışma odalarının akustik durumlarının, öğrencilerin çalgı performansı sırasında dikkat ve meditasyon (rahatlama) düzeylerinin ne derecede etkilediğini tespit etmek ve olası problemlere çözüm bulmaktır. Bu kapsamda, öğrencilerin çalışma odalarındaki çalgı performansları, akustik açıdan farklılıklara göre ele alınarak; elde edilen verilere göre çalışma odalarının düzenlenmesi, öğrencilerin daha verimli ortamlarda çalışmalarına olanak sağlanmasının önemine dikkat çekmek amaçlanmıştır.

Bireysel çalışma odalarındaki akustik durumlara göre farklı çalgıların dikkat ve meditasyon süreçlerinin nasıl etkilendiğine dikkat çekmek, mevcut olan ve yeni yapılacak olan müzik kurumlarındaki çalışma odalarının akustik donanımları hakkında fikir vermek, ayrıca benzer çalışmalara örnek olması ve kaynak oluşturması bakımından araştırmanın önemli olduğu düşünülmektedir. Yapılan araştırmanın müzik eğitimi alanında, çalgı eğitimi performanslarına etki eden beyin temelli oda akustiğine ilişkin yapılan ilk çalışma olması bakımından özgün değer taşıdığı düşünülmektedir. Araştırmada elde edilen bulgular sonucunda yeni araştırmalar ve projelerin gelişmesine temel oluşturabileceği düşünülmektedir. 


\section{Kuramsal Çerçeve}

\section{Neurosky Mindwave Mobile 2 EEG Cihazı}

Insan beyninde miyarlarca nöron bulunmaktadır. Nöronların birbirleriyle etkileşimi sonucunda ortaya çıkan küçük elektriksel dürtüler, beyin dalgaları olarak nitelendirilmektedir. Bu beyin dalgalarını ölçmek ve anlamlandırmak amacıyla Neurosky firması, taşınabilir, tek elektrotlu, kulak klipsli ve alın bölgesinden kuru ölçüm yapan Mindwave Mobile 2 EEG kulaklık setini üretmiştir. Referans noktaları olan alın bölgesindeki elektrot ve kulak klipsi beyin dalgalarını algılar. Cihazın içindeki Thinkgear çipine gelerek zihinsel durumlara arayüz oluşturarak dikkat ve meditasyon verilerine dönüştürülür. Bu veriler bluetooth teknolojisi ile bilgisayar ortamına iletir ve farklı yazılımlar aracığı ile sayısal verilere dönüştürülür. Ölçümler sonucunda ulaşılan sayısal verilerde, ölçü birimi olarak eSense ifadesiyle adlandırılmıştır. eSense, Neurosky'ın tescilli algoritmasıdır (Mindwave User Guide, 2018).

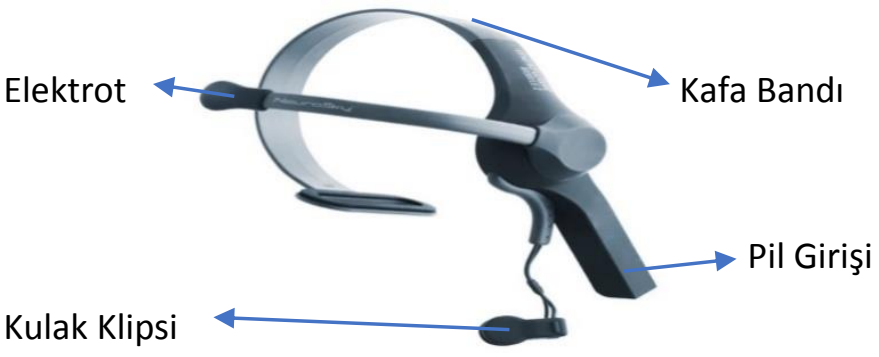

Şekil 1. Neurosky Mindwave Mobile 2 (erişim adresi: www.neurosky.com)

Cihazın beyin dalgalarını anlamlandırma prensibine bakıldığında dikkat eSense verisi, kişinin odaklanma seviyesinin veya yoğun konsantrasyon sırasında ortaya çıkan ve yönlendirilen (istikrarlı) zihinsel aktivitedir. Meditasyon eSense verisi ise rahatlatma ve sakinlik sırasında ortaya çıkan zihinsel aktivitedir (Mindwave User Guide, 2018). İki verinin değeri 0 ile 100 eSense birim arasında değişmektedir. Odaklanamama, endişe, gerginlik gibi hisler bu verileri düşürmektedir.

Neurosky Mindwave Mobile 2 cihazı bluetooth teknolojisi ile bilgisayara tanıtılır. ThinkGear Connector programıyla verilerin işleneceği yazılım ile eşleştirilir. Verilerin işlenmesi konusunda Neuro Experimenter, Brainwave Visualizer, EEG Analyzer, EEG meditation gibi birçok yazılım bulunmaktadır. Bu araştırma için Neurosky'ın resmi sitesinde yer alan Neuro Experimenter Version 6.2 yazılımı kullanılmıştır. Bu yazılımın amacı; meditasyon, gevşeme, konsantrasyon, vb. farklı "zihin durumlarını" denerken beyin dalgası çıktılarını keşfetmektir (Neuro Experimenter User's Guide, 2020).

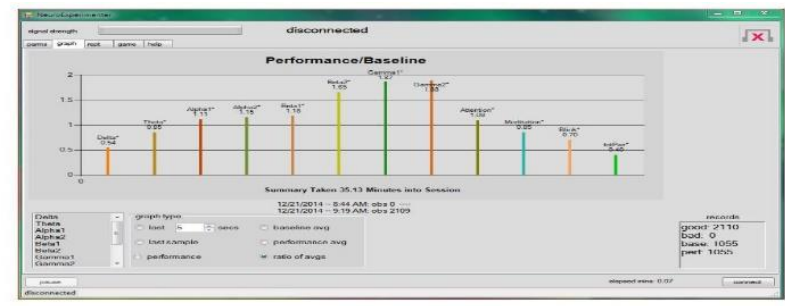

Şekil 2. Neuro Experimenter Bilgisayar Arayüzü (Neuro Experimenter User's Guide, 2020). 
Neurosky Mindwave Mobile 2, Neuro Experimenter yazılımı ile eşleştirildikten sonra istenilen süre aralığında ölçme imkanı sağlamaktadır. Ayrıca yazılım dikkat ve meditasyon verisi haricinde normalleştirilmiş ham beyin dalgaları (delta, theta, alpha, beta, gama) ve göz kırpma verileri gibi farklı ölçümler de yapmaktadır. Ayrıca formül girişleri ile farklı algoritmalar yaratılarak ölçümler yapılabilmektedir. Veri çıktıları ayrı bir sayfada rapor halinde, ölçülen süre zarfında toplam kaç ölçüm yaptığı, ortalama, en düşük ve en yüksek değer şeklinde listelenmektedir.

\section{Akustik Açıdan Yalıtım (İzolasyon) ve Düzenleme}

Durak ve Baytemur'a (2019) göre, “müzik teknolojilerinin içerisindeki mekansal akustik değerlendirmeler müzik sanatının vazgeçilmez bir unsurudur" (s. 3). Yalıtılmamış müzik ortamlarındaki seslerin yanıltıcı olması, çalışma süreçlerinde yanlış öğrenmelere sebebiyet verebildiği bilinmektedir. Odalardaki gürültü kontrolü yapmanın iki boyutu vardır. Birinci boyutu akustik açıdan ses yalıtımı (izolasyon), ikinci boyutu ise oda içerisinde ses kaynağından çıkan sesleri kontrol altına almak için akustik düzenlemedir. İzolasyonun amacı, dışarıdaki seslerin içeri, içerideki seslerin dışarı çıkmasını önlemektir (Önen, 2017). Akustik düzenleme ise oda içerisindeki seslerin, oda özelliklerinden kaynaklı farklılaşmaması (kırınım, yansıma vb.) için belirli ölçüm teknikleri ile yapılan işlemlerdir (Tarikci, 2015). Yalıtım süngerleri, panelleri, taş yünü, bas trap vb. ürünler bu teknikte kullanılan malzemelerdendir.

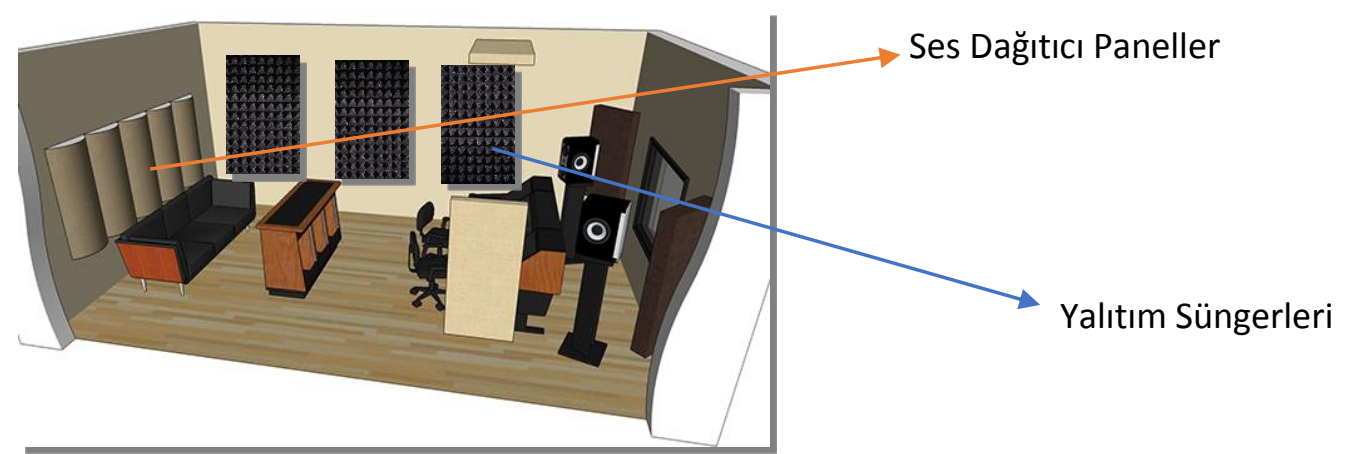

Şekil 3. Akustik açıdan düzenlemiş örnek oda görseli (erişim adresi: www.akustikmimarlik.com)

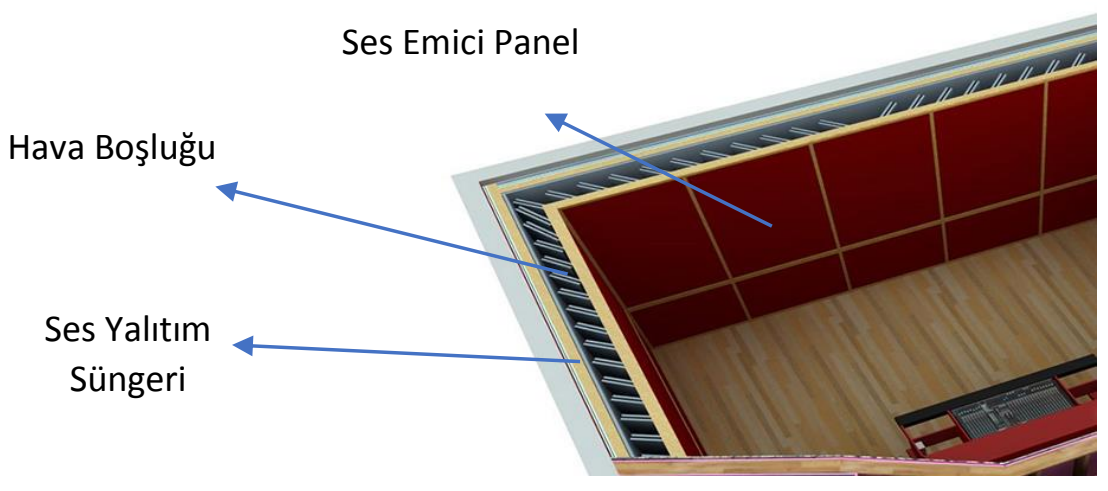

Şekil 4. Akustik ses yalıtımlı örnek yüzer oda görseli (erişim adresi: www.akustikmimarlik.com) 


\section{Yöntem}

\section{Araştırmanın Modeli}

Bu araştırma nitel destekli nicel araştırma modeliyle kurgulanmıştır. Araştırmada yarı deneysel araştırma modelinden kontrol grupsuz son test desen ve nitel araştırma yöntemlerinden uygulama öncesi ve sonrası için yapılandırılmış görüşme formları kullanılmıştır.

"Deneyden önce herhangi bir işlem yapılmamaktadır. Bu desende grubun kendi içinde deney değişkeninin, yani bağımsız (neden) değişkeninin etkisi araştırılmaktadır. Kontrol grubu olmadığından, diğer bir grupla karşılaştırmaya gidilmemektedir. Ayrıca gruba ön test verilmemektedir. Grubu oluşturan bireylerin uygulamanın sonundaki denel işlemden kaynaklanan değişmeleri ölçülmekte ve bir karara varılmaktadır" Sönmez ve Alacapınar (2013, s.57).

Bolu Abant İzzet Baysal Üniversitesi Eğitim Fakültesi Güzel Sanatlar Eğitimi Bölümü Müzik Eğitimi Anabilim Dalı’nda öğrenim gören lisans son sınıf öğrencilerinden çalgı performanslarına ilişkin iki kategorili (akustik açıdan yalıtılmış ve yalıtılmamış) bireysel çalgı odası değişkeni üzerindeki etkisine bakılmıştır. Uygulama öncesi çalışma ile ilgili tüm etik izinler (Bolu Abant izzet Baysal Üniversitesi Klinik Araştırmaları Etik Kurulu, sayı:354, karar no:2020/147, tarih: 22/07/2020) alınmıştır. Her öğrenci, belirlediği bir eseri akustik açıdan yalıtılmamış odada ayrı ayrı üçer oturumlar halinde Neurosky's Mindwave Mobile 2 cihazı takılı iken performanslarını sergilemişlerdir. Ayrı bir günde de aynı eseri akustik açıdan yalıtılmış odada üç oturum olacak şekilde sergilemişlerdir. Katılımcıların kullanılan cihaz takılı iken çalgı çalmaya alışma süreçleri ve farklı bir akustik ortamdaki çalgı seslerine alışma süreçleri göz önüne alınarak, ölçümler üç oturumun ortalamasına göre değerlendirilmiştir. Bu sebeple üç oturumdan elde edilen bulgular yorumlanmamış, katılımcıların çalgı performans süreçlerinin üç oturumu birden ele alınarak ortalamalarının yer aldığı grafikler üzerinden yorum yapılmıştır. Her oturumun dikkat ve meditasyon değerleri Neuro Experimenter programı ile kaydedilmiş ve oturumların ortalamaları alınmıştır. Odalarda gerçekleştirilen performanslara ilişkin ölçümlerin ortalamaları karşılaştırılarak elde edilen sonuçlar uzman desteği ile yorumlanmıştır.

\section{Çalışma Grubu}

Bolu Abant İzzet Baysal Üniversitesi Eğitim Fakültesi Güzel Sanatlar Eğitimi Bölümü Müzik Eğitimi Anabilim Dalı'nda öğrenim gören (2019 - 2020 öğretim yılı) lisans son sınıf öğrencilerinden oluşmaktadır. Araştırmanın deney aşamasına müzik eğitimi anabilim dalındaki her bir çalgıdan (bağlama, gitar, bireysel ses eğitimi, piyano, keman, viyola, viyolonsel, flüt) birer tanesini çalan toplam sekiz öğrenci katılmıştır.

Katılımcılar, bazı ölçütler göz önünde bulundurularak belirlenmiştir. Bunlar;

- Lisans son sınıf öğrencisi olma,

- Çalgı hâkimiyetinin iyi düzeyde olması,

- Öğrenim hayatında ulaştığı yeterli müzikal seviye,

- Çalışma odalarında edindiği deneyimlemeler sonucunda oluşturduğu akustik bilinç, özelliklerine göre çalgı öğretmenlerinin referansı, not ortalaması, yer aldığı konserler ve danışman onayı ile seçilmiştir. 


\section{Veri Toplama Yöntemleri ve Verilerin Analizi}

Araştırma verilerinin toplanmasında, betimsel olarak kaynak tarama, deney öncesi ve sonrası için yapılandırılmış görüşme formları ile nitel araştırma teknikleri ve deney aşamasında farklı akustik ortamların çalgı performanslarına etkisini ölçmek için Neurosky's Mindwave Mobile 2 EEG kulaklık seti kullanılmıştır.

Neurosky's Mindwave Mobile 2 EEG cihazının geçerlilik ve güvenirliği için araştırmalara bakıldığında, Rebolledo-Mendes, Dunwell, Martvnes-Miron, Vargas-Cerdan, de Freitas, Liarokapis ve Garcva - Gaona (2009), cihazın kullanılabilirliğini test etmek için elektrotun elektrik sinyalleri ölçülmüştür (Akt. İnel 2014). Sonuçlara göre dikkat seviyeleri arasında pozitif bir korelasyon olduğunu görülmüştür. Crowley, Sliney ve Murphy (2010), araştırmalarında psikolojik temelli testler kullanarak cihazın dikkat ve meditasyon seviyelerini ölçmüşlerdir. İki çalışmada da cihaz katılımcılar üzerinde denenmiştir ve sonuçlar doğrultusunda Neurosky's Mindwave, minimal bir invaziv bir ölçüm aracı olarak verilerin doğruluğunun uygun olduğunu belirtmişlerdir (Akt. İnel, 2014). Ayrıca Rogers, Johnstone, Aminov, Donnelly ve Wilson (2016), geleneksel laboratuvar EEG ekipmanları ile Neurosky's Mindwave cihazının test-tekrar-test yöntemini kullanarak güvenirlik seviyelerini araştırmışlardır. Belli yaş gruplarına uygulayarak elde edilen verilere göre orta düzeyde cihazı güvenilir bulmuşlardır.

Uygulama öncesi için hazırlanan yapılandırılmış görüşme formunda katılımcıların uygulama standardını sağlamak için sorular yer almaktadır. Katılımcılara uygulama ile ilgili gerekli bilgilendirmeler yapılmış ve bu form ile katılımcılara uygulama öncesi açlık, uyku, sağlık durumu, performansa yönelik hazırlığı vb. konularla ilgili sorular sorularak tüm katılımcıların uygulama sürecinin aynı şartlarda yapılması sağlanmıştır. Görüşme sonrası ortaya çıkan verilere bakıldığında katılımcıların standart şartlarda (uygulama öncesi açlık, uyku, sağlık vb. durumlarının farklı olmadığı) uygulamaya katıldıkları görülmüştür.

Uygulama sonrası için hazırlanan yarı yapılandırılmış görüşme formunda ise katılımcıların uygulama sonrası deneyim ve tercihlerinin uygulama verileri ile tutarlılı̆ını karşılaştırmak adına sorular hazırlanmıştır. Büyüköztürk, Kılıç Çakmak, Akgün, Karadeniz ve Demirel'e (2018, s.159) göre, yarı yapılandırılmış görüşmelerin, sabit seçenekli cevaplamayla verilerin hızlı elde edilebilmesi ve analizinin daha kolay olması ayrıca ilgili alanda derinlemesine bilgi toplanması açısından avantajı bir veri toplama tekniği olduğunu belirtmişlerdir. Yarı yapılandırılmış görüşme, uygulamanın etkileri geçmeden uygulama biter bitmez uygulanmıştır. Görüşme sonrası tüm cevaplar tek tek incelenmiş, raporlanmış ve bulgular bölümünde yer verilmiştir.

Uygulama aşamasında ise tüm katılımcılar iki farklı akustik ortamda farklı günlerde performans sergilemişlerdir. Önce akustik açıdan yalıtılmamış odada sonra ise yalıtılmış odada çalgılarını icra etmişlerdir. Performans sırasında katılımcılar Neurosky's Mindwave Mobile 2 cihazını takmışlardır ve dikkat - meditasyon verileri anlık olarak bluetooth teknolojisi ile bilgisayara aktarılmıştır. Veriler bilgisayara Neuro Experimenter programıyla aktarılmış ve kaydedilen veriler ekran görüntüsü ile arşivlenmiş̧ir. Elde edilen dikkat ve meditasyon değerleri sütun grafikleri ile gösterilmiş ve frekans analizleri yapılmıştır. 


\section{Deneysel İşlem Basamakları}

- Katılımcılara göre hazırlanan plan doğrultusunda uygulama, önce akustik açıdan yalıtılmamış bireysel çalışma odasında yapılmıştır.

- Oda özelliklerine bakıldığında; $6 \mathrm{mt}^{2}$ büyüklüğünde, beton duvar ve tavan, yarıya kadar yağlı boyalı, yerler mermer, bir adet boy aynası ve odada tek ses soğurucu eşya iki kapılı ahşap dolaptan oluşmaktadır.

- Cihaz ile bilgisayar bağlantıları yapılmış ve tekrar test edilmiştir.

- Her katılımcıya uygulama öncesi açıık, uyku, sağlık durumu, performansa yönelik hazırlığı vb. konuları içeren görüşme soruları sorulmuştur.

- Uygulama öncesi katılımcıların oda akustiğine alışmaları açısından prova şansı verilmiş ve kendilerini hazır hissettiklerinde uygulama aşamasına geçilmiştir.

- Uygulama, üç oturum ve her oturumun ölçüm süresi beşer dakika olmak üzere belirlenmiştir.

- Her oturumdan sonra ara verilmiş ve katılımcının kendisini hazır hissetmesiyle diğer oturuma geçilmiştir.

- Akustik açıdan yalıtılmamış oda ölçümlerinde katılımcı çalgısını icra ederken 50-60dB arası oda dışında olacak şekilde dış ortam gürültüsü verilmiştir. Ortam gürültüsünün desibeli taşınabilir Unı-t marka mini bir desibelmetre ile ölçülmüştür.

- Katılımcı uygulama öncesi belirlediği eser veya etüdü Neurosky's Mindwave Mobile 2 cihazı takılı iken çalgısı ile seslendirmiş, bu aşamadaki dikkat ve meditasyon verileri gerçek zamanlı olarak kaydedilmiştir.

- Bu aşamalar tüm katılımcılar için tamamlandıktan sonra aynı işlem basamakları akustik açıdan yalıtılmış bireysel çalışma odasında da tekrarlanmıştır.

- Tüm uygulamalar bittikten sonra katılımcılara uygulama sonrası yarı yapılandırılmış görüşme soruları yöneltilmiştir.

- Akustik açıdan yalıtılmış ve düzenlenmiş oda seçiminde yapılan görüşmeler sonucunda, hacim akustiği düzenleme yazılımlarıyla uzman kişiler tarafından yapılan bir stüdyo seçilmiştir.

\section{Bulgular}

Araştırmanın ilk bölümünde katılımcılar, akustik açıdan yalıtılmamış odada 3 oturum halinde performans sergilemişlerdir. Araştırmanın ikinci bölümünde ise öğrenciler aynı şekilde akustik açıdan yalıtılmış ve düzenlenmiş odada 3 oturum halinde Neurosky Mindwave Mobile 2 cihazı takılı iken performanslarını sergilemişlerdir. Her iki odada alınan dikkat ve meditasyon verilerinin ortalamaları alınmış ve karşılaştırılmıştır. 


\section{Uygulama Bulguları}

Bağlama Katılımcısının iki Farklı Akustik Ortamdaki Dikkat ve Meditasyon Veri Ortalamalarının Karşılaştırılması

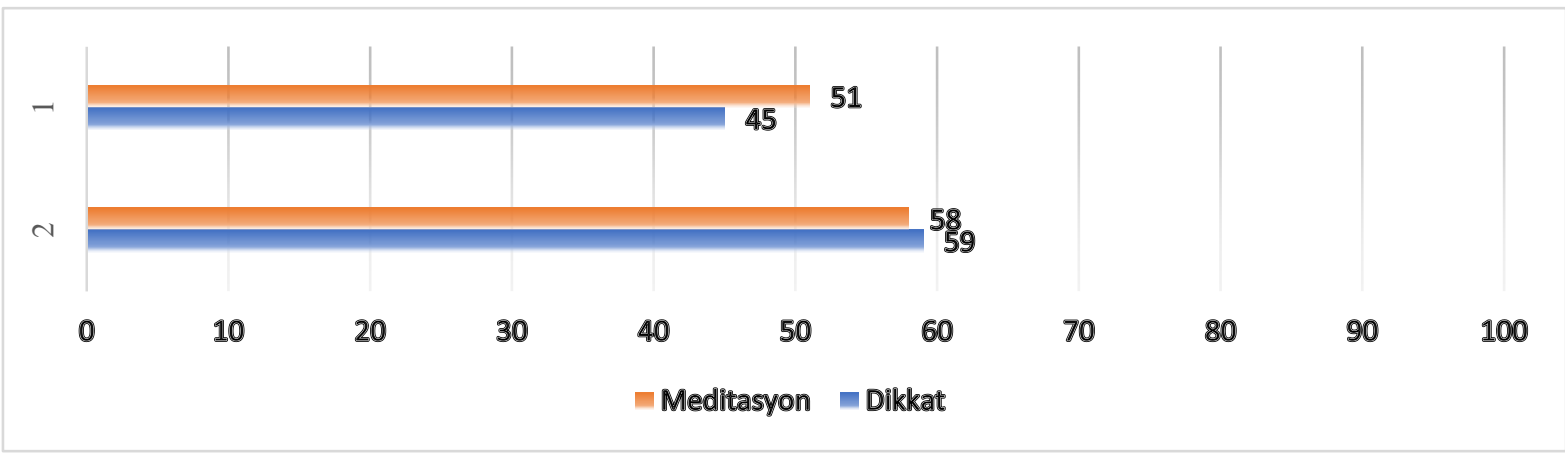

Grafik 1. Bağlama katılımcısının akustik açıdan yalıtılmış ve yalıtılmamış odadaki performanslarının, dikkat ve meditasyon verileri ortalamalarının karşılaştırılması

Not: 1- Yalıtılmamış Oda Perf. Ort. / 2- Yalıtılmış Oda Perf. Ort

Grafik 1'e bakıldığında bağlama katılımcısının iki farklı akustik ortamda sergilediği çalgı performansının, dikkat ve meditasyon ortalamaları karşılaştırımıştır. Katılımcının akustik açıdan yalıtılmamış oda verilerine bakıldığında dikkat değeri 45 , meditasyon değeri ise 51 olarak görülmektedir. Akustik açıdan yalıtılmış oda verilerine bakıldığında ise dikkat değeri 59, meditasyon değeri ise 58 olarak görülmektedir. İki farklı odadaki veriler karşılaştırıldığında hem dikkat hem de meditasyon değerinin akustik açıdan yalıtılmış odada daha fazla olduğu saptanmıştır. Akustik açıdan yalıtılmış odadaki dikkat verisi, yalıtılmamış oda verisinden 14 birim daha fazladır. Yine akustik açıdan yalıtılmış odadaki meditasyon verisi, yalıtılmamış oda verisinden 7 birim daha fazladır. Dolayısıyla bağlama katılımcısının yalıtılmış odadaki performansından elde edilen ölçüm ortalamalarında hem dikkat hem de meditasyon değerlerinde artış olduğu, bunun oda değişkenine göre farklılık gösterdiği görülmüştür. Yalıtılmış odanın, katılımcının çalgı performansındaki dikkat ve meditasyon değerlerini olumlu yönde etkilediği söyleyebilir.

Gitar Katılımcısının iki Farklı Akustik Ortamdaki Dikkat ve Meditasyon Veri Ortalamalarının Karşılaştırılması

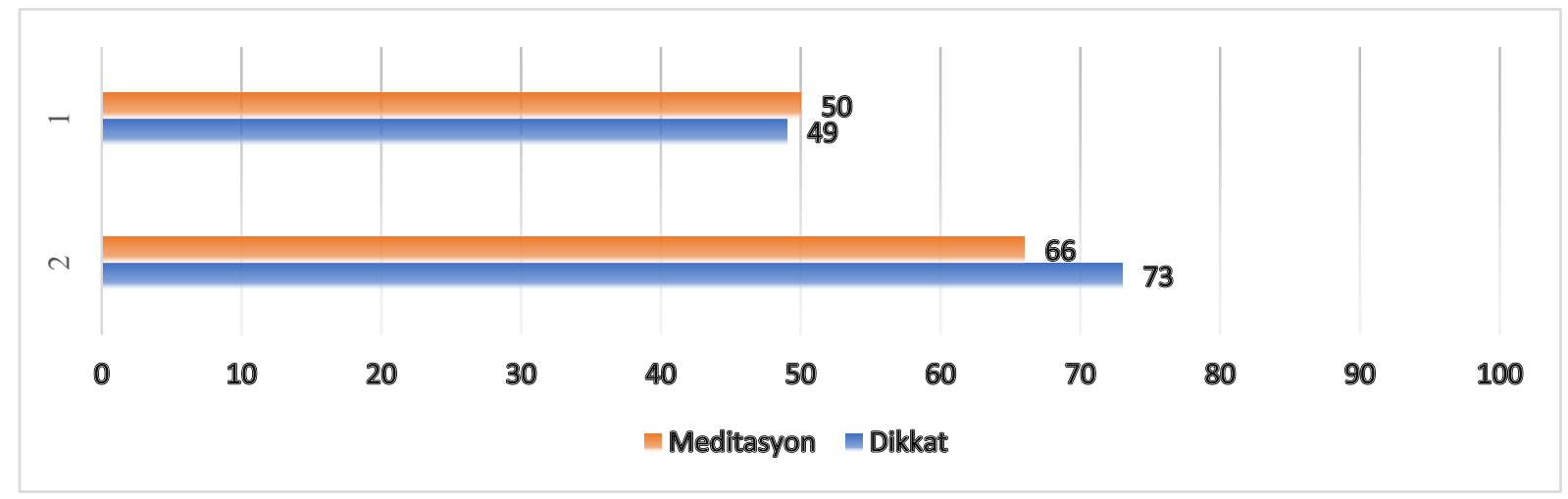

Grafik 2. Gitar katılımcısının akustik açıdan yalıtılmış ve yalıtılmamış odadaki performanslarının, dikkat ve meditasyon verileri ortalamalarının karşılaştırılması

Not: 1- Yalıtımamış Oda Perf. Ort. / 2- Yalıtılmış Oda Perf. Ort 
Grafik 2'ye bakıldığında gitar katılımcısının iki farklı akustik ortamda sergilediği çalgı performansının, dikkat ve meditasyon ortalamaları karşılaştırılmıştır. Katılımcının akustik açıdan yalıtılmamış oda verilerine bakıldığında dikkat değeri 49, meditasyon değeri ise 50 olarak görülmektedir. Akustik açıdan yalıtılmış oda verilerine bakıldığında ise dikkat değeri 73 , meditasyon değeri ise 66 olarak görülmektedir. İki farklı odadaki veriler karşılaştırıldığında hem dikkat hem de meditasyon değerinin akustik açıdan yalıtılmış odada daha fazla olduğu görülmektedir. Akustik açıdan yalıtı ımıs odadaki dikkat verisi, yalıtılmamış oda verisinden 24 birim daha fazladır. Yine akustik açıdan yalıtılmış odadaki meditasyon verisi, yalıtılmamış oda verisinden 16 birim daha fazladır. Gitar katılımcısının yalıtılmış odadaki dikkat ve meditasyon değerlerinin yüksek olması, katılımcının dış uyaranlardan korunmuş bir ortamda odaklanarak kendi öz denetimini gerçekleştirebilmesine olanak tanımasından kaynaklanabilir. Dolayısıyla yalıtılmış oda faktörü katılımcının dikkat ve meditasyon değerlerini pozitif yönde etkilediği saptanmıştır.

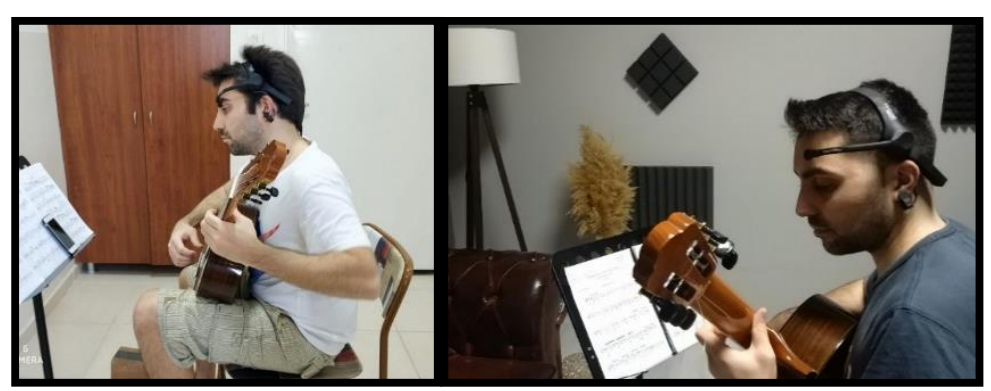

Şekil 5. Farklı akustik ortamlarda gitar katılımcısının uygulama görselleri

\section{Flüt Katılımcısının iki Farklı Akustik Ortamdaki Dikkat ve Meditasyon Veri Ortalamalarının Karşılaştırılması}

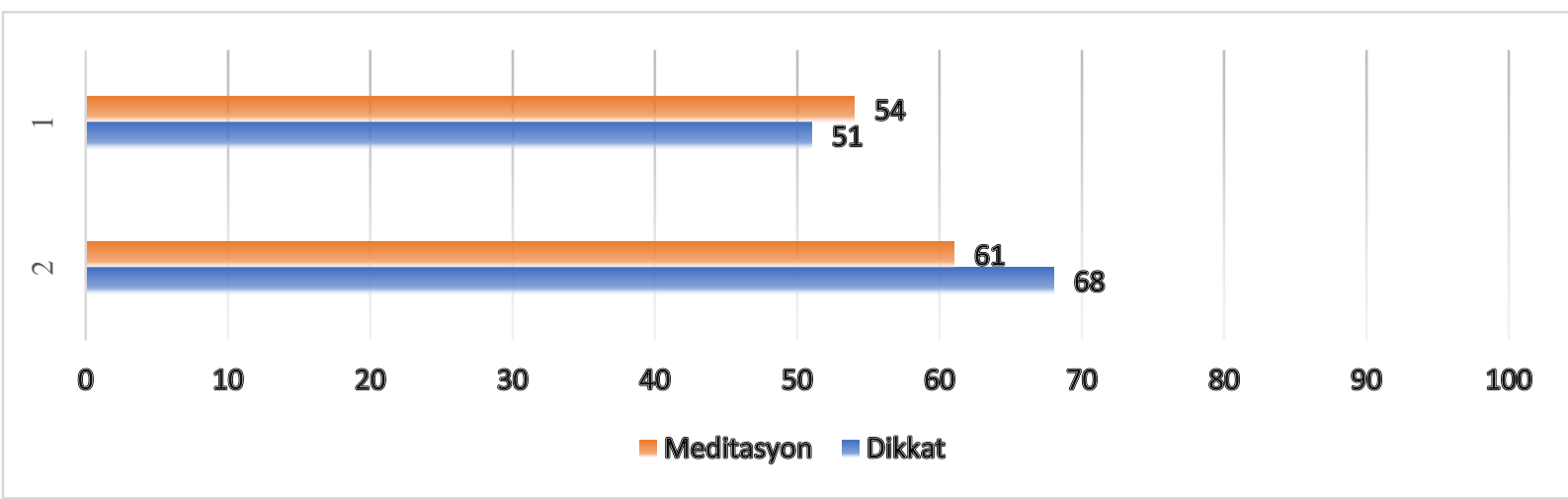

Grafik 3. Flüt katııımcısının akustik açıdan yalıtılmış ve yalıtılmamış odadaki performanslarının, dikkat ve meditasyon verileri ortalamalarının karşılaştırılması

Not: 1- Yalıtılmamış Oda Perf. Ort. / 2- Yalıtılmış Oda Perf. Ort

Grafik 3'e bakıldığında flüt katıımcısının iki farklı akustik ortamda sergilediği çalgı performansının, dikkat ve meditasyon ortalamaları karşılaştırılmıştır. Katılımcının akustik açıdan yalıtılmamış oda verilerine bakıldığında dikkat değeri 51, meditasyon değeri ise 54 olarak görülmektedir. Akustik açıdan yalıtılmış oda verilerine bakıldığında ise dikkat değeri 68 , meditasyon değeri ise 61 olarak görülmektedir. ỉki farklı odadaki veriler karşılaştırıldığında hem dikkat hem de meditasyon değerinin akustik açıdan yalıtılmış odada daha fazla olduğu görülmektedir. Akustik açıdan yalıtılmış odadaki dikkat verisi, yalıtılmamış oda verisinden 17 birim daha fazladır. Yine akustik açıdan 
yalıtılmış odadaki meditasyon verisi, yalıtılmamış oda verisinden 7 birim daha fazladır. Flüt katılımcısının yalııılmış odada gerçekleştirmiş olduğu çalgı performansının dikkat ve meditasyon değerleri bakımından yükseldiği, bu yükselişin seslerin yansımamasına bağlı olarak kendini duyabilme ve dinleyebilme süreçlerine odaklanarak destek olmasına bağlanabilir. Çelik (2010, s. 790) müzikalitenin sağlanması ve gelişiminde; çalma ile ilgili teknik sorunların çözülmüş olması, kendini dinleme (duyma) alışkanlığının oluşmuş olması, form- armoni, stil bilgisi ile genel kültür ve duyarlılı̆ın gelişmiş olması koşullarının sağlanabilmesine değinmiştir. Aynı zamanda kendi performansına odaklanmanın müzikaliteyi arttırabilecek bir unsur olduğu düşünülürse meditasyon değerlerindeki artışın etkilenmesine sebep olabilir.

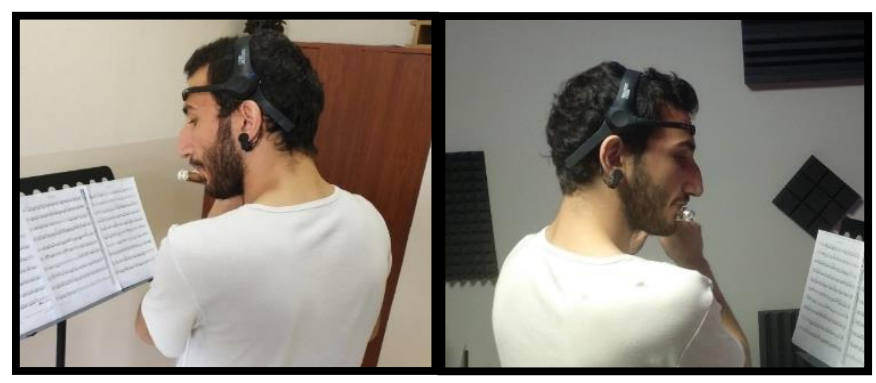

Şekil 6. Farklı akustik ortamlarda flüt katılımcısının uygulama görselleri

\section{Bireysel Ses Eğitimi Katılımcısının iki Farklı Akustik Ortamdaki Dikkat ve Meditasyon Veri Ortalamalarının Karşılaştırılması}

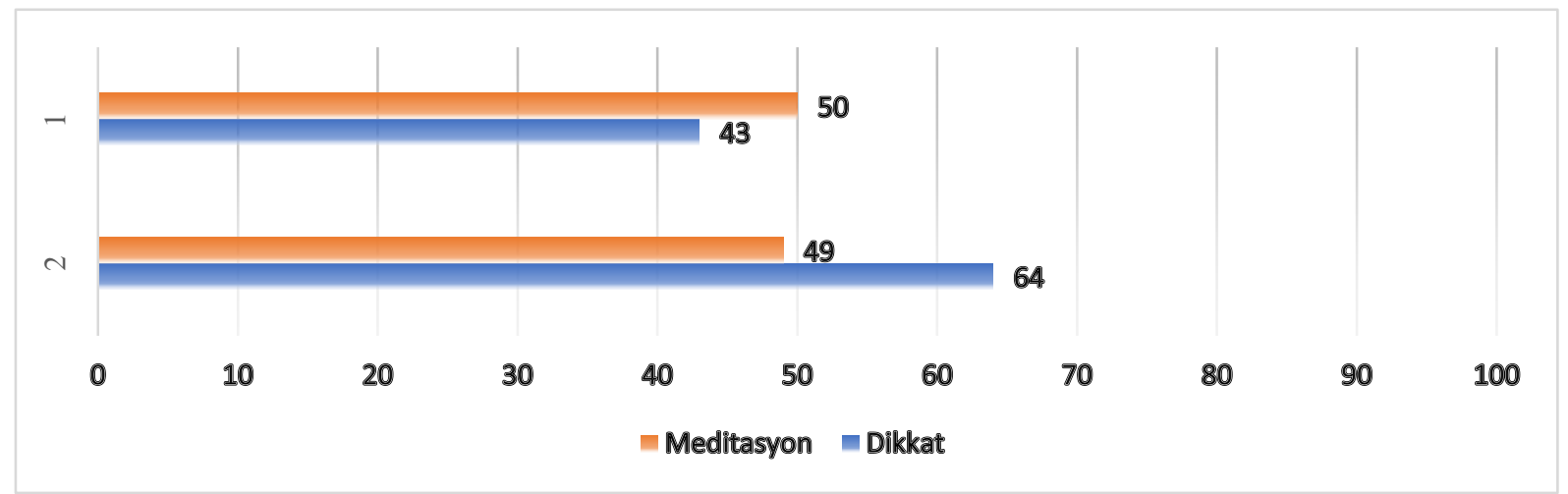

Grafik 4. Bireysel ses eğitimi katılımcısının akustik açıdan yalıtılmış ve yalıtılmamış odadaki performanslarının, dikkat ve meditasyon verileri ortalamalarının karşılaştırılması

Not: 1- Yalıtılmamış Oda Perf. Ort. / 2- Yalıtılmış Oda Perf. Ort

Grafik 4'e bakıldığında bireysel ses eğitimi katılımcısının iki farklı akustik ortamda sergilediği çalgı performansının, dikkat ve meditasyon ortalamaları karşılaştırıımıştır. Katılımcının akustik açıdan yalıtılmamış oda verilerine bakıldığında dikkat değeri 43 , meditasyon değeri ise 50 olarak görülmektedir. Akustik açıdan yalıtılmıs oda verilerine bakıldığında ise dikkat değeri 64 , meditasyon değeri ise 49 olarak görülmektedir. İki farkı odadaki veriler karşılaştırıldığında dikkat değerinin akustik açıdan yalıtılmış odada fazla ama meditasyon değerinin akustik açıdan yalıtılmamış odada daha fazla olduğu görülmektedir. Aradaki fark incelendiğinde çok yüksek bir değer olmadığı bir birim olarak kaşımıza çıktığı tespit edilmiştir. Ancak akustik açıdan yalıtılmış odadaki dikkat verisi, yalıtılmamış oda verisinden 21 birim daha fazladır. Bireysel ses eğitimi katılımcısının dikkat değerleri ortalamasının yalıtı ımıs odada yüksek çıkması, uyaran ses faktörlerinin en aza indiği bir atmosfere 
sahip olmasından kaynaklanabilir. Otacıoğlu (2020), bir sesin üretiminde akustik açıdan nasıl duyulduğunun önemli olduğu belirtmiştir. Buna bağlı olarak meditasyon değerleri arasında anlamlı bir fark ortaya çıkmamış, yalıtılmamış oda faktörünün ses eğitiminde akustik açıdan ses rezonansını sağlaması dikkat değerlerini olumlu yönde etkilemiş olabilir.

\section{Keman Katılımcısının iki Farklı Akustik Ortamdaki Dikkat ve Meditasyon Veri Ortalamalarının Karşılaştırılması}

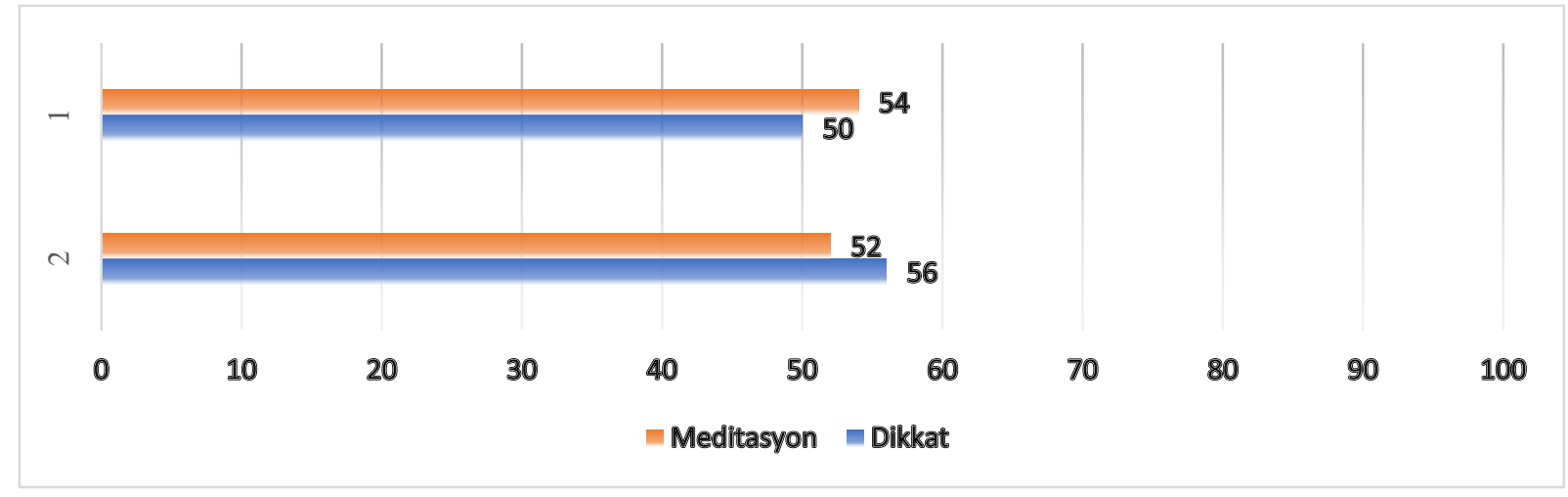

Grafik 5. Keman katılımcısının akustik açıdan yalıtılmıs ve yalıtılmamış odadaki performanslarının, dikkat ve meditasyon verileri ortalamalarının karşılaştırılması

Not: 1- Yalıtılmamış Oda Perf. Ort. / 2- Yalıtılmış Oda Perf. Ort

Grafik 5'e bakıldığında keman katılımcısının iki farklı akustik ortamda sergilediği çalgı performansının, dikkat ve meditasyon ortalamaları karşılaştırılmıştır. Katılımının akustik açıdan yalıtılmamış oda verilerine bakıldığında dikkat değeri 50 , meditasyon değeri ise 54 olarak görülmektedir. Akustik açıdan yalıtılmış oda verilerine bakıldığında ise dikkat değeri 56, meditasyon değeri ise 52 olarak görülmektedir. ìki farkı odadaki veriler karşılaştırıldığında dikkat değerinin akustik açıdan yalıtıımış odada fazla ama meditasyon değerinin akustik açıdan yalıtılmamış odada daha fazla olduğu görülmektedir. Akustik açıdan yalıtılmış odadaki dikkat verisi, yalıtılmamış oda verisinden 6 birim daha fazladır. Akustik açıdan yalıtılmamış odadaki meditasyon verisi, yalıtılmış oda verisinden 2 birim daha fazladır. Keman katılımcısının yalıtımış odada dikkat değerlerinin yüksek çıktığı ancak yalıtılmamış odada meditasyon değerinin daha yüksek olduğu görülmüştür. Dikkat değerlerinin yalıtılmış odada yüksek çıkması her katılımcıda olduğu gibi olağan ve tutarlıdır. Ancak meditasyon değerinin yalıtılmamış odada yüksek olması kişinin performansında oluşan farklılıklardan kaynaklanmış olabilir. Bu farklılıklar ayrı oturumlarda gerçekleşen performansların tutarlılık göstermemesinden ve doğru - temiz çalma parametrelerinde farklılık yaratmasından dolayı meditasyon değerini etkilemiş olabilir. Ya da ortam akustik parametreleriyle alakalı olduğu yönünden ele alınırsa, ortam gürültüsünün meditasyon değerini düşürürken, kendi performansının rahatlık içinde gerçekleştirmesi dikkat değerini yükseltmiş olabilir. 


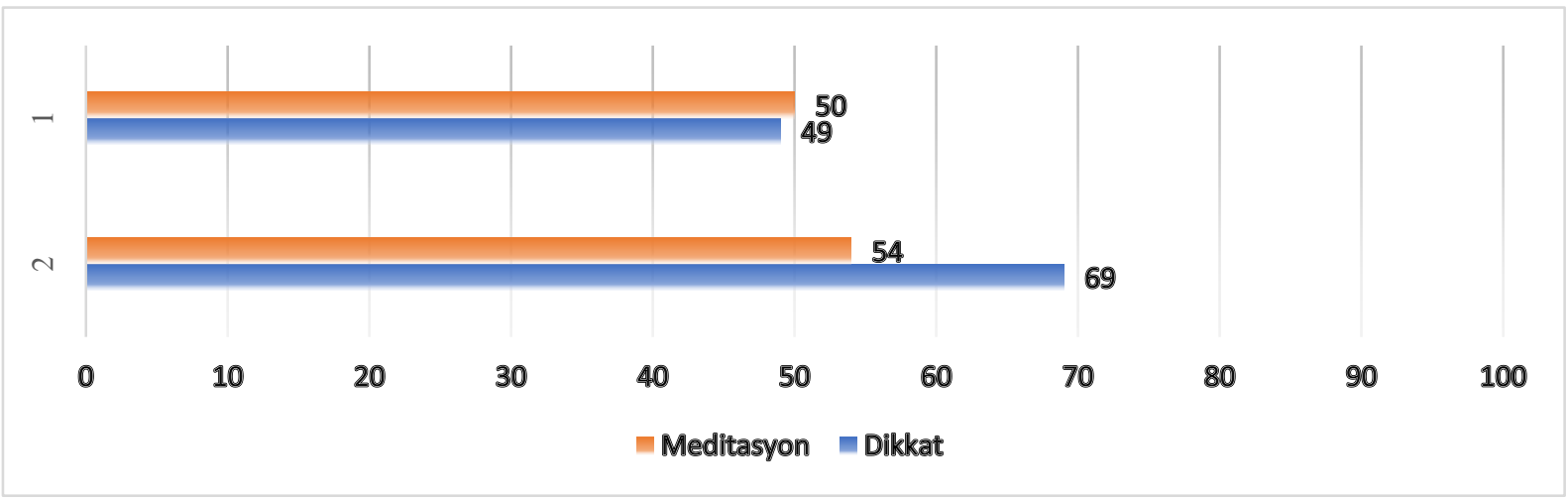

Grafik 6. Viyola katılımcısının akustik açıdan yalıtılmış ve yalıtılmamış odadaki performanslarının, dikkat ve meditasyon verileri ortalamalarının karşılaştırılması

Not: 1- Yalıtılmamış Oda Perf. Ort. / 2- Yalıtılmış Oda Perf. Ort

Grafik 6’ya bakıldığında viyola katılımcısının iki farklı akustik ortamda sergilediği çalgı performansının, dikkat ve meditasyon ortalamaları karşılaştırılmıştır. Katılımcının akustik açıdan yalıtılmamış oda verilerine bakıldığında dikkat değeri 49 , meditasyon değeri ise 50 olarak görülmektedir. Akustik açıdan yalıtılmış oda verilerine bakıldığında ise dikkat değeri 69 , meditasyon değeri ise 54 olarak görülmektedir. ỉki farklı odadaki veriler karşılaştırıldığında hem dikkat hem de meditasyon değerinin akustik açıdan yalıtılmış odada daha fazla olduğu görülmektedir. Akustik açıdan yalıtımış odadaki dikkat verisi, yalıtılmamış oda verisinden 20 birim daha fazladır. Yine akustik açıdan yalıtılmıs odadaki meditasyon verisi, yalıtılmamış oda verisinden 4 birim daha fazladır. Viyola katılımcısının dikkat ve meditasyon değerleri paralellik göstermiş, her iki değerde yalıtılmış odada yükselmiştir. Bu durum katılımcının oturumlarda gerçekleştirmiş olduğu performanslarının birbiri ile tutarlı ve paralel olduğu göstermiş, katılımcının yalıtılmış odada meditasyon ve dikkat değerlerinin olumlu yönde etkilendiği görülmüştür.

Viyolonsel Katılımcısının iki Farklı Akustik Ortamdaki Dikkat ve Meditasyon Veri Ortalamalarının Karşılaştırılması

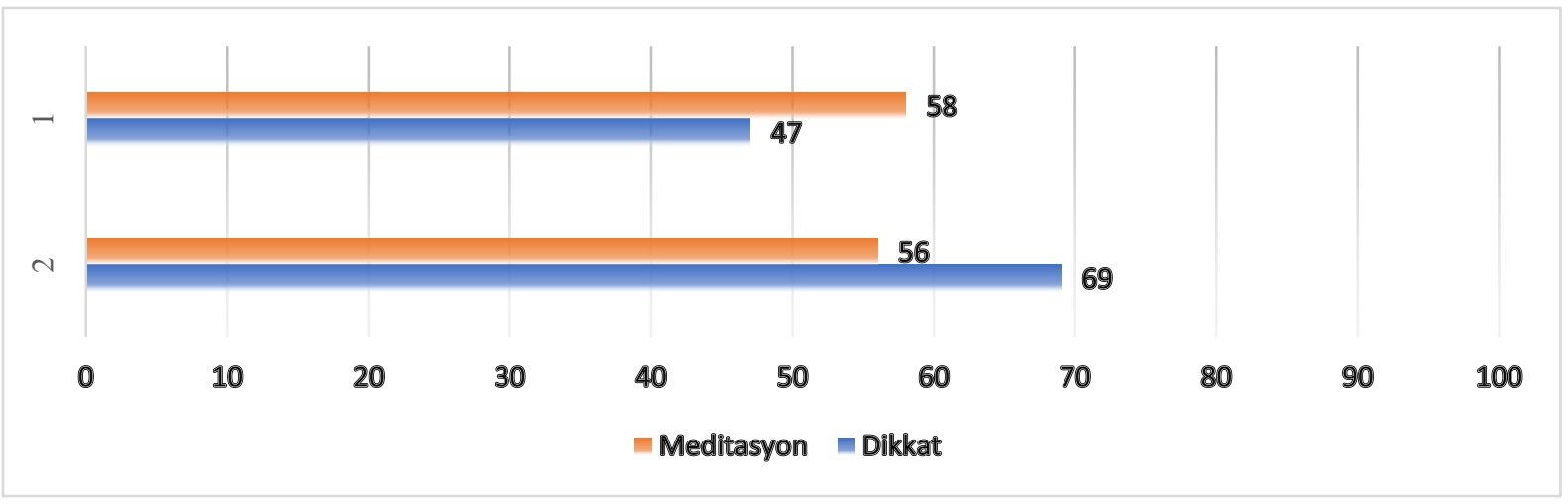

Grafik 7. Viyolonsel katılımcısının akustik açıdan yalıtılmış ve yalıtılmamış odadaki performanslarının, dikkat ve meditasyon verileri ortalamalarının karşılaştırılması

Not: 1- Yalıtılmamış Oda Perf. Ort. / 2- Yalıtılmış Oda Perf. Ort 
Grafik 7'ye bakıldığında viyolonsel katılımcısının iki farklı akustik ortamda sergilediği çalgı performansının, dikkat ve meditasyon ortalamaları karşılaştırılmıştır. Katılımcının akustik açıdan yalıtılmamış oda verilerine bakıldığında dikkat değeri 47, meditasyon değeri ise 58 olarak görülmektedir. Akustik açıdan yalıtılmış oda verilerine bakıldığında ise dikkat değeri 69 , meditasyon değeri ise 56 olarak görülmektedir. İi farklı odadaki veriler karşılaştırıldığında dikkat değerinin akustik açıdan yalıtılmış odada fazla ama meditasyon değerinin akustik açıdan yalıtılmamış odada daha fazla olduğu görülmektedir. Akustik açıdan yalıtılmış odadaki dikkat verisi, yalıtılmamış oda verisinden 22 birim daha fazladır. Akustik açıdan yalıtılmamış odadaki meditasyon verisi, yalıtılmış oda verisinden 2 birim daha fazladır. Viyolonsel katılımcısının yalıtılmış odada dikkat değerleri artarken, meditasyon değerleri yalıtımamış odaya göre iki birim düşmüştür. Bunun sebebi kişinin çalgı performansı sırasında zihin ve bedenini aktif olarak kullanması sonucunda uyumunu yakalayabilmesiyle bağlantılıdır olabilir (Arıcı, 2019). Bu durum kişiden kişiye farklılık gösterebilmektedir.

\section{Piyano Katılımcısının iki Farklı Akustik Ortamdaki Dikkat ve Meditasyon Veri Ortalamalarının Karşılaştırılması}

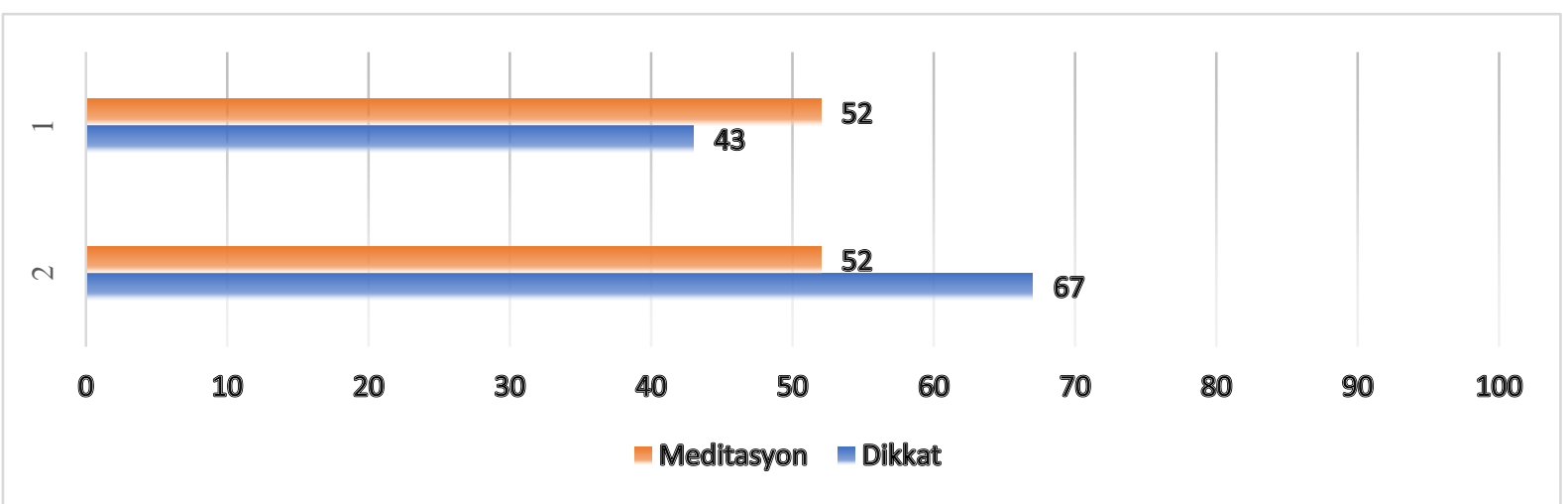

Grafik 8. Piyano katılımcısının akustik açıdan yalıtılmış ve yalıtılmamış odadaki performanslarının, dikkat ve meditasyon verileri ortalamalarının karşılaştırılması

Not: 1- Yalıtılmamış Oda Perf. Ort. / 2- Yalıtıımış Oda Perf. Ort

Grafik 8'e bakıldığında piyano katılımcısının iki farklı akustik ortamda sergilediği çalgı performansının, dikkat ve meditasyon ortalamaları karşılaştırılmıştır. Katılımcının akustik açıdan yalıtılmamış oda verilerine bakıldığında dikkat değeri 43, meditasyon değeri ise 52 olarak görülmektedir. Akustik açıdan yalıtılmış oda verilerine bakıldığında ise dikkat değeri 67 , meditasyon değeri ise 52 olarak görülmektedir. İki farklı odadaki veriler karşılaştırıldığında dikkat değerinin akustik açıdan yalıtı Imış odada fazla ama meditasyon değerinin iki farklı akustik odada aynı olduğu görülmektedir. Akustik açıdan yalıtılmış odadaki dikkat verisi, yalıtılmamış oda verisinden 24 birim daha fazladır. Akustik açıdan yalıtılmış ve yalıtılmamış odadaki meditasyon verileri aynıdır. Piyano katılımcısının yalıtılmış odada dikkat değerleri yüksek iken, meditasyon değerlerinde herhangi bir değişme görülmemiş, aradaki fark nötr olarak karşımıza çıkmıştır. Dikkat değerlerinin yalıtılmış odada yüksek çıkması, seslerin yalıtılmış bir ortamda sadece kendi performansından oluşması nedeniyle odaklanmanın yükselmesini sağlamış olabilir. Meditasyon açısından ele alındığında, iki farklı ortamda 6 oturumun ortalama verilerinin aynı çıkması çok ender bir durum olmakla birlikte, kişide rahatık durumunun ortamlara göre farklılık göstermemesi ancak değer açısından ele alındığında 52 değerinin rahatılı ve meditasyon bakımından iyi bir değer olduğu yorumlanabilir. 


\section{Uygulama Sonrası Görüşme Bulguları}

Her iki akustik ortamda performans sergileyen katılımcılara, uygulama aşamaları doğrultusunda ve akustik odalar ile ilgili toplam beş soru sorulmuştur. Soruların cevapları başlıklar halinde tek tek incelenmiş ve cevaplar betimsel olarak analiz edilmiştir.

Uygulama sonrası yarı yapılandııımış görüşme formu birinci soru cevapları ve analizleri;

Yarı yapılandırılmış görüşme formunun birinci sorusu "Uygulamaya katıldığınız iki farklı çalışma odasından hangisinin çalgı çalışmaya daha uygun olduğunu düşünüyorsunuz?" olarak katılımcılara sorulmuştur. Gelen cevaplar doğrultusunda tüm katılımcılar, akustik açıdan yalıtılmış odanın çalgı çalışma açısından daha uygun olduğunu belirtmiştir.

Uygulama sonrası yarı yapılandırılmış görüşme formu ikinci soru cevapları ve analizleri;

Yarı yapılandırılmış görüşme formunun ikinci sorusu "Uygulamaya katıldığınız iki farklı çalışma odasından hangisinde çalgınızı daha iyi duydunuz?" olarak katılımcılara sorulmuştur. Gelen cevaplar doğrultusunda tüm katılımcılar, akustik açıdan yalıtılmış odada çalgılarını daha iyi duyduğunu belirtmişlerdir. Çalgılarını daha net duyduklarını, bu sayede bastıkları seslerin temiz veya yanlış olup olmadığını daha iyi ayırt ettiklerini de cevaplara eklemişlerdir.

Uygulama sonrası yarı yapılandırılmış görüşme formu üçüncü soru cevapları ve analizleri;

Yarı yapılandırılmış görüşme formunun üçüncü sorusu "Çalgı çalışma odalarında akustik yalıtım ve çalışma ortamının akustik açıdan düzenlenmiş olması sizin için önemli mi? Açıklayınız." olarak katılımcılara sorulmuştur. Gelen cevaplar doğrultusunda katılımcıların tümü, çalgı çalışma odalarında akustik yalıtım ve çalışma ortamının akustik açıdan düzenlenmiş olmasının önemli ve gerekli olduğunu ifade etmişlerdir. Çalgı seslerinin daha net duyulduğunu, esere odaklanmanın daha kolay ve entonasyon sağlamada gerekli olduğunu cevaplara eklemişlerdir. Ayrıca;

- Bağlama katııımcısı, dış dünya ile bağlantısının manevi olarak kopmuş olduğunu ve çalgısı ile daha sağlam bir bağ kurduğunu, bu sayede çalışmasından daha üst düzeyde verim aldığını belirtmiştir.

- Gitar katılımcısı, yalıtılmış odada bir eseri çalarken veya deşifre ederken sağlıklı ses duymanın odaklanmayı, dolayısıyla verimi çok daha artırdığını, yalıtılmamış odada çalışırken ise tıpkı bir konser sırasında gürültülü bir dinleyici varken ne kadar verim alınabilirse ancak o kadar verim alınabileceğini ifade etmiştir.

- Bireysel ses eğitimi katılımcı ise farkıı bir görüş olarak yalıtılmış odanın gerekliliğini fakat akustik açıdan düzenlenmiş odada reverb gibi efektlerin oluşmamasından dolayı motivasyonu olumsuz etkilediğini belirtmiştir. İnsan sesinin doğal bir çalgı olması nedeniyle ortam akustiğinden daha çok etkilenmeye müsait olduğu düşünülebilir.

* Uygulama sonrası yarı yapılandırılmış görüşme formu dördüncü soru cevapları ve analizleri;

Yarı yapılandırılmış görüşme formunun dördüncü sorusu "Yalııılmamış odada çalgı performansı sırasında dış gürültüler esere odaklanmanızı etkilemekte mi? Açıklayınız." olarak katılımcılara sorulmuştur. Gelen cevaplar doğrultusunda katılımcıların çoğu dış gürültülerin çalışma sırasında esere odaklanmayı zorlaştırdığını belirtmiştir. Sadece keman katılımcısı müzik öğrenimi boyunca hep dış gürültülere maruz kaldığını ve süreç içerisinde bu gürültülere karşı duyarsızlaştığını ifade etmiştir. Ayrıca katılımcılar, dış gürültülerin çalışma süresini kısalttığını, dikkatin dağılmasıyla eserin yarıda kesildiğini, dağılan dikkatin toparlanmaya çalışılması ile vakit kaybının yaşanmasını cevaplarına eklemişlerdir. 
Uygulama sonrası yarı yapılandırılmış görüşme formu beşinci soru cevapları ve analizleri;

Yarı yapılandırılmış görüşme formunun beşinci sorusu “Aynı eseri yorumlarken iki farklı odanın çalgı performansınıza yansımaları nasıl olmuştur? Olumlu - olumsuz yanlarını benzer ve farklı yönlerini ele alarak açıklayınız" olarak katılımcılara sorulmuştur. Gelen cevaplar doğrultusunda;

- Bağlama katıımcısı, "yalıtılmış odada çalgımın sesini duyabildiğim için yanlışlarımı fark edip, bu yanlışları düzeltebiliyordum. Ancak yalıtılmamış odada hatalarımı duyma olanağım neredeyse yoktu. Yalıtılmış odada çalgım ile bütünleşebildim ve konsantrasyonum daha iyiydi. Bu nedenle yaptı̌̆ım çalışma çok daha verimliydi. Yalıtılmış oda dış seslerin bana ulaşmasını engellediği için çalışmamın çok daha faydalı olduğunu düşünüyorum. Yalıtılmamış odada ise gürültü nedeni ile çalışmakta çok zorlandım. Yalıtılmış oda akustik olarak yalıtılmış ve düzenlenmiş olduğu için duyduğum tek şey çalgımın sesiydi. Yalıtılmamış odada ise enstrümanımın sesi yankılanarak tekrar tekrar bana geri ulaşıyor bu nedenle dikkatim çok dağılıyordu ve çalgıma odaklanmakta çok güçlük çektim" olarak düşüncelerini belirtmiştir.

- Gitar katılımcısı, "çalgım gitar olduğu için bir viyolonsel veya akustik bir piyano kadar gürlüğe sahip değil. Bu sebeple gürültülü bir ortamda çalgının sesini duymak oldukça zorlaşıyor. Duyum olmadığı takdirde enstrümanda verimli çalışma neredeyse imkansız hale geliyor. Fakat yalıtılmış bir odada dışarıdan gelen seslere rağmen böyle bir problem olmuyor. Çünkü enstrümanın sesini bastıracak kadar bir gürültü, olağanüstü şartlar dışında zaten odada duyulmuyor" olarak düşüncelerini belirtmiştir.

- Flüt katılımcısı, "akustik açıdan yalıımlı odanın olumlu yanı, dışarıdan ses gelmemesi dikkatimin artmasını sağladı, daha çok verim aldığımı hissettim, olumsuz herhangi bir etken olduğunu düşünmüyorum" ifadelerini kullanmıştır.

- Bireysel ses eğitimi katılımcısı, "yalıtımlı odada eserimi seslendirirken hatalarımı, sesleri, nefes kullanımını daha net görebildim. Çünkü çok daha kendinle birlikte oluyorsun ve dışarıdan seni rahatsız edecek herhangi bir ses vs. gelmiyor. Yalıtımsız odada çalışırken eserle bütünleşemedim çünkü aklım hep beni rahatsız eden gürültüdeydi. Şöyle bir durum da var yalıtımlı odada eserden ve çalışmamdan aldığım keyif daha azdı. Çünkü yalıtılmamış odada akustik olarak ses daha güzel uzuyordu, daha az hata belli ediyordu, bu da benim eseri seslendirirken motivasyonumu yükseltiyordu ve daha çok keyif alıyordum." olarak düşüncelerini cevaplara eklemiştir.

- Keman katılımcısı, "akustik açıdan düzenlenmemiş odada reverb vardı ve pis seslerimi duymuyordum. Kulağa da hoş geliyordu ama aslında iyi bir performans sergilemiyordum. Ses yalıımlı ortamda pis sesler kulağımı tırmaladı ve duyup düzeltmem daha rahat oldu.

- Viyola katılımcısı, "yalıtımlı odada kendimi daha net duyduğum için yapmış olduğum hataları fark edip düzeltme imkânı bulmuştum. Fakat yalıtılmamış odada ise ne çalarsam güzel tınlıyordu, bunun nedeni sesin çok fazla yankılanmasından kaynaklı olmasıydı. Bu nedenle her zaman yalıtımlı oda da çalışmanın daha faydalı olduğunu görmüş oldum" olarak düşüncelerini cevaplara eklemiştir.

- Viyolonsel katılımcısı, "yalıtıımamış odada çalgı çalarken esere duygusal açıdan daha fazla yaklaşabildim fakat yalıtılmış odada çalıştığım esere daha kolay odaklanabildim, dikkatimi toplayabildim. Çalışmak için yalıtılmış oda esere odaklanma ve entonasyon temizleme açısından daha verimli bir ortam sunuyor." olarak düşüncelerini belirtmiştir.

- Piyano katılımcısı, "ilk yapılan uygulamada dışardan gelen gürültüler parçaya odaklanmamda zorluk yaratsa da sonrasında kendimi toparlamaya çalışım. Tabi bu aşamada müzikalite arka planda kalmıs oldu. Uygulamanın 2. aşamasında ise sessiz bir ortamda istediğim gibi müzikalite yaparak parçama odağım daha rahat ve yüksekti" ifadelerini kullanmıştır. 


\section{Tartışma, Sonuç ve Öneriler}

Çalgı eğitiminde çalışma süreci, provalar ve sahne performansı sırasında konsantrasyon çok önemli bir otokontroldür. Konsantrasyonu etkileyen dış faktörler (gürültü, ISI, ışık, ortam durumları vb.) çalgı performansını büyük ölçüde olumsuz olarak etkilemektedir. Çalgı eğitimi verilen kurumlarda, oda durumlarından kaynaklı yaşanılan problemler arasında akustik problemler (ses yalıtımının olmaması, fazla reverb ve echo vb.), diğer problemlere göre (ısı, temizlik ışık vb.) çalgı performansını daha fazla etkilediği düşünülmektedir. Türkiye'deki müzik eğitimi verilen kurumlar incelendiğinde de çalışma odalarında yeterli akustik donanım bulunmamaktadır.

Araştırmanın verileri incelendiğinde iki oda arasındaki farklar, çalgılara göre değişiklik göstermiştir. Bu verilere göre akustik açıdan iki odada sergilenen çalgı performanslarında, katılımcıların meditasyon verilerinde bireysel farklılıklar görülmektedir. Buna göre odanın akustik farklılı̆ı katılımcıların meditasyon değerlerinde farklı çalgıların çalışma prensiplerine ve rezonans alışkanlıklarına göre değişiklik göstermiştir. Altında yatan sebepler irdelendiğinde esere olan dikkat süresi arttıkça nota ve çalma tekniklerine olan yoğunlaşma yorumdan uzaklaşmaya ve kişilerde eserin yarattığı duygusal dışa vurumu gerçekleştirememeye neden olduğu düşünülmektedir. Çalgı performansı anlıktır ve geri alınamaz. Bu sebeple hata yapmamak için dikkat süreleri ve değeri arttıkça, rahatlık ve müzikalite süreçlerinden uzaklaşmalar yaşanabilir. Alexander (2016), öğrencilerin hata yapmaktan korkmayacakları, müzikal riskler alabilecekleri güvenli bir öğrenme ortamının oluşturulması gerektiğini söyleyerek, öğrenme ortamlarının yaratıcı deneyimler sunması gerektiğini belirtmiştir (Akt. Çenberci, 2019, s.107). Bu sebeple katılımcılardan bazılarında hatalara odaklanmanın meditasyon değerinin düşmesine sebebiyet verdiği düşünülebilir. Bu anlamda elde edilen bulgular bireylerin çalışma alışkanlıklarında edindikleri ortam deneyimlerinin bulundukları ortamlara göre farklı hislere sebep olduğunu, bu yüzden çalışma alışkanlıklarının sağlıklı, verimli ve temiz duyumlarla çalışılabilecek ortam düzenlemelerinin sağlanması gerektiği sonucu ile yorumlanabilir.

Yapılan uygulama ile şu sonuçlara ulaşılmıştır.

- Tüm katılıııların farklı akustik ortamda sergiledikleri performansa göre dikkat değerleri, akustik açıdan yalıtılmış odada 6 birimden 24 birime kadar pozitif yönlü farklılık göstererek daha yüksek çıkmıştır. Bu sonuçtan yola çıkılarak akustik açıdan yalıtılmış ve düzenlenmiş odada çalgı eğitimi ve performanslarına yönelik öğrencilerin dikkatleri, odaklanmaları ve konsantrasyonları daha iyi düzeyde olacağı söylenebilir.

- Tüm katılıcıların sergiledikleri performansa göre meditasyon değerlerinde bireysel farklılıklar ortaya çıkmıştır. Bağlama, gitar, flüt, viyola katılımcıların yüksek; bireysel ses eğitimi, keman, viyolonsel katılımcıların düşük ve piyano katılımcısının nötr yönlü veri farkı görülmektedir. Fakat, negatif yönlü veriler incelendiğinde farkın en fazla 2 birim olduğu, buna göre de meditasyon verileri düşük çıkan katılımcıların, iki farklı akustik odada aslında birbirlerinden çok farklı olmadığı tespit edilmiştir. Altında yatan sebepler irdelendiğinde esere olan dikkat süresi arttıkça nota ve çalma tekniklerine olan yoğunlaşma yorumdan uzaklaşmaya ve kişilerde eserin yarattığı duygusal dışa vurumu gerçekleştirememeye neden olduğu düşünülmektedir.

- Uygulama sonrası yapılan görüşmelerde tüm katılımcıların çalgı çalışma ortamı bakımından akustik açıdan yalıtılmış odayı tercih ettikleri, bu tür odalarda çalgılarına daha iyi odaklandıklarını ve konsantrasyonlarını daha iyi toparladıklarını belirtmişlerdir. Fakat bazı katılımcılar akustik açıdan düzenlenmiş odalarda performans sergilemenin daha zor olduğunu, çalgı öğrenim süreçlerinde bu tür odalarda çalışmadıkları için işitsel olarak daha farklı geldiğini dile getirmişlerdir. Yalıtılmış odada kendi öz denetimlerinin gerçekleştirebilme durumlarını dile getirerek, bu odada çalışmanın daha zor ancak verimli olabileceğini 
belirtmişlerdir. Sonuç olarak katılımcıların oda alışanlıklarının dolaylı bir şekilde meditasyon düzeyini etkilediği düşünülmektedir.

- Çalgı türlerine bakıldığında; telli - mızraplı, yaylı, nefesli ve tuşlu çalgılar arasında veriler karşılaştırıldığında bir bağlantı görülmemiştir. Arıcı (2019), "çalgı çalma eyleminde zihin ve beden aktif olarak kullanılır. Dolayısıyla bireylerin sergiledikleri çalgı performanslarının kişiden kişiye farklılık gösterdiği ve bu farklııkta çalgı ile zihnin ve bedenin uyumunun da oldukça önemli bir rol oynadığı söylenebilir" (s.21-22).

- iki farklı akustik oda verileri dikkat ve meditasyon verileri açısından incelendiğinde; akustik açıdan yalıtılmamış oda verilerinde meditasyon, akustik açıdan yalıtılmış ve düzenlenmiş oda verilerinde ise dikkat değerleri daha yüksek çıkmıştır. Buna göre de, akustik açıdan yalıtılmış odalarda çalgı eğitimi, öğrencilerde dikkat ve konsantrasyonu daha iyi düzeyde tutacağı söylenebilir.

Incelenen araştırmalar ve tez sonucundan yola çıkılarak aşağıda verilen öneriler ile çalgı eğitimine ve sonraki çalışmalara katkıda sağlayacağı düşünülmektedir.

- Çalgı eğitiminin daha verimli olması bakımından mesleki müzik kurumlarının bireysel çalışma odalarında akustik yalıtıma ve düzenlemelere gidilmesinin yararlı olacağı düşünülmektedir.

- Bireysel çalışma sürecinde çevresel koşulların çalgı performanslarına ve kalıcı yönde davranış gerçekleştirebilme üzerine etkisini, Durak ve Baytemur (2019, s.3), "doğru bir duyum ve kendini dinleyerek değerlendirme doğru akustikte daha gerçekçi olacaktır" ifadesiyle dile getirmişlerdir.

- Akustik açıdan düzenlenmiş odada sesler geri dönmediği için reverb, echo, delay gibi sesi güzelleştiren efektler oluşmaz. Çalgıdan çıkan ses kulağa ham haliyle gelir ve varsa entonasyon hataları direkt olarak duyulur. Bu yüzden çalgı performansı bu tür odalarda sergilemek zordur. Stüdyo kayıtlarında performans sergileyen müzisyenler böyle ortamlarda çalgılarını icra ederler ve kaydın mükemmel olması gerektiğinden metronom ile senkron hataları, nota ve entonasyon hataları vb. çalım sıkıntıları olmadan geri dönüşümsüz odada bunu gerçekleştirirler. Akustik açıdan düzenlenmiş odada çalgı çalışmak bu bağlamda zamanla özdenetimi arttırır, çalgıda uzmanlaşma doğru ve sağlıklı bir şekilde gerçekleşir. Bu bağlamda akustik açıdan yalıtılmış ve düzenlenmiş odalar uzman kişiler tarafından standart bir oda modeli şeklinde oluşturulmalıdır. Böylelikle, öğrenim gören kişiler, farklı işitsel algılardan zamanla kurtulabilir ve performans verimi arttırılabilir.

- Yeni yapılacak olan mesleki müzik kurumlarının konumlandırıması hususunda, dış ortam gürültülerine maruz kalmayacakları en uygun yerler seçilmelidir. Ayrıca en baştan akustik tedbir doğrultusunda mimarisi planlanmalıdır. Öğrencilerin, çalışma odalarında uzun süre kalıp çalışabilecekleri ortamlar yaratılmalıdır.

- Öğrencilerin odalarda yaşadıkları akustik problemleri anlamlandırması ve gidermesi açısından örgün eğitim ders içeriklerine akustik alanında daha fazla ders eklenmelidir.

- Araştırmanın çalışma grubu yeni yapılacak araştırmalar ile genişletilebilir ve daha büyük gruplar ile farklı değişkenler (yaş, cinsiyet, çalgı türleri, ölçüm süresi, farklı EEG cihazı vb.) açısından incelenebilir. Böylece daha farklı sonuçlar ile literatüre ve bilime yenilikler getirilebilir. 


\section{Kaynakça}

Akgün, M. (2011). Müzik çalışma odalarının akustik olarak objektif ve sübjektif parametreler aracılığıyla kritik analizinin yapılması: örnek durum incelemesi; ihsan Doğramacı Bilkent Üniversitesi mssf binası (Yüksek lisans tezi, Hacettepe Üniversitesi) YÖK Ulusal Tez Merkezi veri tabanından erişildi. (Erişim No: 308520)

Arıcı, G. (2019). Mesleki müzik eğitimi alan öğrencilerin çalgıya yönelik benlik algıları ile sürekli optimal performans duygu durumları arasındaki ilişkinin incelenmesi. (Yüksek lisans tezi, Ondokuz Mayıs Üniversitesi) YÖK Ulusal Tez Merkezi veri tabanından erişildi. (Erişim No: 535224)

Aşmet Köse, A. (2004). Abant lizzet Baysal Üniversitesi eğitim fakültesi güzel sanatlar eğitimi bölümü müzik eğitimi anabilim dalı bireysel çalışma odalarının akustik özelliklerinin müzik eğitimine eğitimci ve öğrenci açısından yansıması. (Yüksek lisans tezi, Bolu Abant İzzet Baysal Üniversitesi) YÖK Ulusal Tez Merkezi veri tabanından erişildi. (Erişim No: 144034)

Ayata, E., ve Aşkın, C. (2008, Aralık). Müziğin beynin bilişsel fonksiyonlarına olan etkisi. İü Sosyal Bilimler Dergisi/B, 5(2).

Bulunuz, M., Bulunuz, N., ve Tuncal, J. K. (2017). Akustik iyileştirme yapılmış bir okulda gürültü düzeyinin değerlendirilmesi. Eğitimde Kuram ve Uygulama, 13(4), 637-658.

Büyüköztürk, Ş., Kılıç Çakmak. E., Akgün, Ö. E., Karadeniz, Ş. ve Demirel, F. (2018). Bilimsel araştırma yöntemleri. Pegem akademi.

Crowley, K., Sliney, A. ve Murphy, D. (2010, July). Evaluating a brain-computer interface to categorise human emotional response. $10^{\text {th }}$ IEEE International conference on advanced learning technologies.

Çelik, B. (2010). Piyano eğitiminde video kamera kullanımı. Gazi Üniversitesi Gazi Eğitim Fakültesi Dergisi, 30(3).

Çenberci, S. (2019, 10-12 Eylül). Eğitim bilimleri teori, güncel araştırmalar ve yeni eğilimler (Şahin, H. Ed.). Çalgı eğitiminde güdülenmeyi sağlamaya ve sürdürmeye yönelik yöntemler (Bölüm VII, s. 100 - 111). ISBN: 978-9940-46-049-5. IVPE.

Daloğlu, C. (2019). Özel dersliklerin akustik performans sınıfları ve akustik proje tanımları kapsamında değerlendirilmesi: İmir B.B müzik sanat atölyeleri örneği. (Yüksek lisans tezi, Dokuz Eylül Üniversitesi) YÖK Ulusal Tez Merkezi veri tabanından erişildi. (Erişim No: 574606)

Demirkale, S. Y. (2007). Çevre ve yapı akustiği: mimarlar ve mühendisler için el kitabı. Birsen yayınevi.

Durak, Y. ve Baytemur, S. (2019, 4-7 Eylül). Müzik teknolojilerinin müzik eğitimi kurumlarında adaptasyonu. iSME İstanbul 2019 Legacy Congerence

İnel, Y. (2014). Sosyal bilgiler öğretiminde kullanılan bilgisayar temelli materyallerin 6. sınıf öğrencilerinin dikkat ve motivasyon düzeylerine etkisi. (Doktora tezi, Gazi Üniversitesi) YÖK Ulusal Tez Merkezi veri tabanından erişildi. (Erişim No: 381573)

Jelen, B. (2013). Türkiye'de müzik öğretmeni yetiştirme sürecinde piyano eğitiminde karşılaşılan sorunlar. Rast Musicology Journal, 1(1), 258-285. http://dx.doi.org/10.12975/rastmd.2013.01.01.0011

Kurtyener, K. (2019). Akustik ve çevresel gürültü ölçüm sistemlerinin irdelenmesi - mevcutlara alternatif taşınabilir ve çok noktada ölçüm yapabilen bir modelin geliştirilmesi. (Yüksek lisans tezi, Dokuz Eylül Üniversitesi) YÖK Ulusal Tez Merkezi veri tabanından erişildi. (Erişim No: 600501)

Levitin, D.J. (2015). Müziğin etkisindeki beyin (A.S. Çulhaoğlu, Çev.) Pegasus yayınları:1168

Mindwave User Guide. (2018). 29.08.2020 tarihinde http://download.neurosky.com/public/Products/MindWave\%20Mobile\%202/MindWave\%20Mobile\%20 2\%20User\%20Guide\%20.pdf sayfasından indirilmiştir.

Mutlu, T.E. (2018). Doğu anadolu bölgesinde bulunan güzel sanatlar liseleri müzik bölümlerinin mevcut durumlarının öğretmen görüşleri açısından değerlendirilmesi. (Yüksek lisans tezi, Gazi Üniversitesi) YÖK Ulusal Tez Merkezi veri tabanından erişildi. (Erişim No: 533251)

Neuro Experimenter User's Guide (2020). 15.06.2020 tarihinde https://docs.google.com/document/d/1mB1YIZUbSr39ytF5U7u1KHGC0h9220JxVQE8X4yHXs/edit\# sayfasından indirilmiştir.

Otacıoğlu, S. (2020, 21 Eylül). Ses eğitiminde register algısı. Atatürk Üniversitesi sosyal bilimler enstitüsü dergisi, 24(3), 1295-1311. (21.09.2020)

Önen, U. (2017). Ses kayıt ve müzik teknolojileri (10. Baskı). ISBN 978-9944-424-17-2. Çitlembik yayınları.

Özmenteş, S. (2004). Anadolu güzel sanatlar liseleri müzik bölümü öğrencilerinin çalgı çalışma sürecinde karşılaştıkları sorunlar ve çözüm önerileri. (Yüksek lisans tezi, Dokuz Eylül Üniversitesi) YÖK Ulusal Tez Merkezi veri tabanından erişildi. (Erişim No: 145318) 
Özmumcu, E. (2019). Güzel sanatlar lisesi müzik bölümleri çalgı eğitimine yönelik öğretmen ve öğrenci görüşlerinin çeşitli boyutlarıyla incelenmesi. (Yüksek lisans tezi, Tokat Gaziosmanpaşa Üniversitesi) YÖK Ulusal Tez Merkezi veri tabanından erişildi. (Erişim No: 554154)

Parker, B. (2015). Güçlü titreşimler - müziğin fiziği (C. Güray ve M. Sözer, Çev.) Tübitak popüler bilim kitapları 725

Sönmez, V. ve G. Alacapınar, F. (2013). Örneklendirilmiş bilimsel araştırma yöntemleri. Anı yayıncılık.

Şendurur, Y. (2001). Keman eğitimi dersine etkili hazırlanma süreci. Gazi Üniversitesi gazi eğitim fakültesi dergisi, 21(2).

Şendurur, Y., ve Barış, D. A. (2002). Müzik eğitimi ve çocuklarda bilişsel başarı. Gazi Üniversitesi gazi eğitim fakültesi dergisi, 22(1).

Tarikci, A. (2015). Müzik teknolojisine giriş. ISBN 978-605-4957-19-4.Müzik eğitimi yayınları.

Uçan, A. (1997). müzik eğitimi: temel kavramlar-ilkeler-yaklaşımlar. Müzik ansiklopedisi yayınları. 